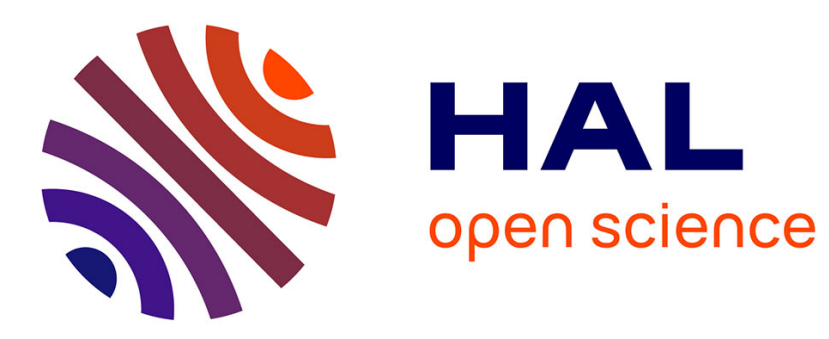

\title{
Glass-mounted high performance electrodes
}

\author{
W. Hänni, D. Morel, H. Hintermann
}

\section{To cite this version:}

W. Hänni, D. Morel, H. Hintermann. Glass-mounted high performance electrodes. Journal de Physique IV Proceedings, 1993, 03 (C7), pp.C7-793-C7-794. 10.1051/jp4:19937125 . jpa-00251744

\section{HAL Id: jpa-00251744 https://hal.science/jpa-00251744}

Submitted on 1 Jan 1993

HAL is a multi-disciplinary open access archive for the deposit and dissemination of scientific research documents, whether they are published or not. The documents may come from teaching and research institutions in France or abroad, or from public or private research centers.
L'archive ouverte pluridisciplinaire HAL, est destinée au dépôt et à la diffusion de documents scientifiques de niveau recherche, publiés ou non, émanant des établissements d'enseignement et de recherche français ou étrangers, des laboratoires publics ou privés. 


\title{
Glass-mounted high performance electrodes
}

\author{
W. HÄNNI, D. MOREL and H.E. HINTERMANN \\ Swiss Center for Electronics and Microtechnology, Inc., Maladière 71, 2007 Neuchâtel, Switzerland
}

\section{Extended Abstract}

In industry and laboratories there is a need for high duty "feed-through" electrodes with outstanding properties either for sensing and measuring or as a working electrode for high voltage or current. Beside the best possible electrical conductivity, such electrodes have to be resistant to extreme pressure differences such as is found in vacuum chambers or in autoclaves at pressures up to 700 bars or more. Further, they must be resistant to very corrosive and erosive atmospheres encountered with either solid, liquid or gaseous chemicals, and perhaps additionally at elevated temperatures. For analytical or synthesis work in biochemistry for the development of pharmaceutical products the biocompatibility of the system is evident. It is often difficult to find a commercially available electrode which satisfies simultaneously all these requirements.

The paper presents results of development work on an electrode based on a carbon-densified graphite or glassy carbon conductor cast in borosilicate glass (1) at approximately $1100^{\circ} \mathrm{C}$. Carbon materials do not wet borosilicate glass. In order to obtain a leak-proof bond between the carbon-based electrode and the glass, the conducting material previously received a CVD coating based on Si. An approximately $10 \mu \mathrm{m}$ thick coating is applied at a temperature of $1250^{\circ}$ $\mathrm{C}$, near the melting point of $\mathrm{Si}$ in a ordinary $\mathrm{H}_{2} / \mathrm{SiCl}_{3}$ gas phase, at reduced pressure. At this temperature it is presumed that an extremely thin layer of $\mathrm{SiC}$ will naturally occur between the carbon-based material and the Si coating. This intermediate layer will be responsible for good bonding of the Si to the substrate. Silicon oxidizes at its surface once exposed to humid air. Even if very thin, this oxide layer helps, on the other hand, to achieve good contact with any glass material. The thus prepared carbon-based electrode is fixed in a graphite crucible in which a borosilicate glass cylinder is also placed. The crucible is degased in high vacuum during the first heating cycle. Once a temperature of $500^{\circ} \mathrm{C}$ is reached, the vacuum is replaced by a suitable gas to avoid evaporation and to prevent severe loss of compounds such as sodium and phosphorus during melting of the glass. By respecting of all parameters necessary for melting and treating borosilicate glass, the $\mathrm{Si}$-coated carbon electrode is guaranteed to be imbedded free of gas bubbles. The glass-insulated carbon electrode is then mechanically cut to the desired parts. Before polishing the final electrode, a short heat treatment is made to avoid mechanical stress.

No gas leakage could be observed with flat feed-through electrodes of this type, having a wall thickness of approximately $4 \mathrm{~mm}$, against a high pressure chamber at 700 bar in a HPLC detector cell (see figure).

The typical application fields include: electrochemical detectors for HPLC, electrochemical treatment of polluted water with atomic oxygen to destroy poisonous organic compounds, feedthrough electrodes of all applications for vacuum vessels, high pressure technology such as for autoclaves, high temperature applications in combustion engines, etc. ... 
Other common electrode materials (e.g. copper, silver, gold, platinum, molybdenum or tungsten) can also be fitted to glass. More sophisticated electrode materials for example titanium diboride, tin oxide or even boron-doped diamond or amorphous carbon could be coated on suitable substrates such as glassy carbon or molydenum for very special applications.

[1] J. C. Hooguliet, J. A. G. van Bezooyen, A. C. J. Hermans-Lokkerbol, C. J. van der Poel and W. P. van Bennekom, J. Liquid Chromatography, 6 (1983) 1849

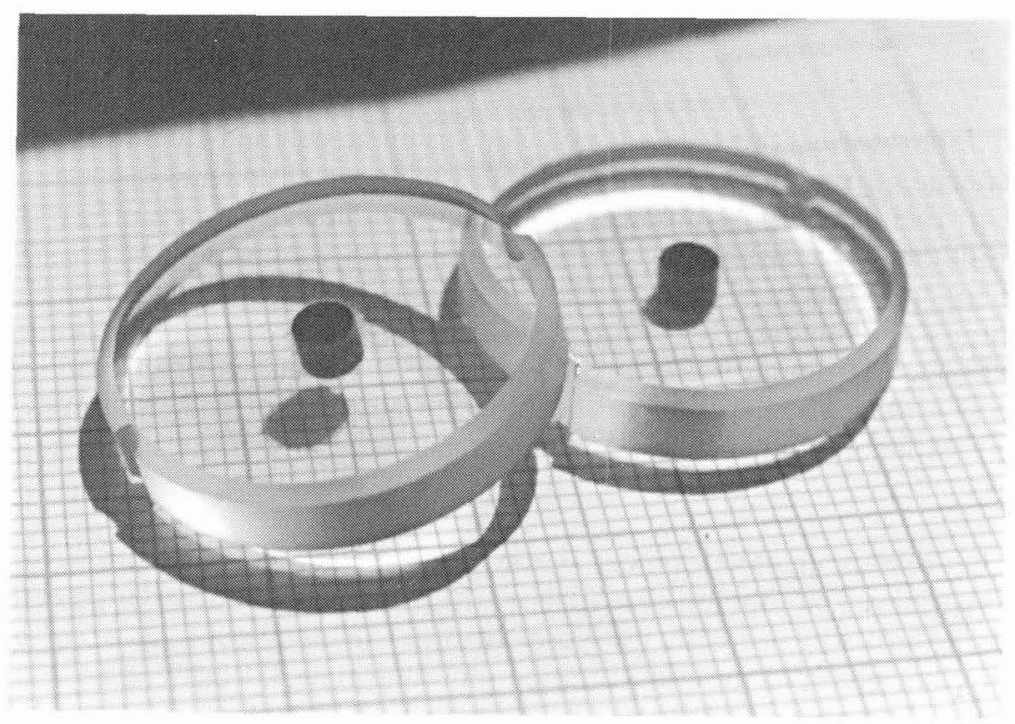

Figure: $\quad$ HPLC Glassy-Carbon Electrodes 